\title{
VERTICAL SAMPLING OF MANTLE BENEATH NORTHEASTERN BRAZIL AS REPRESENTED BY ULTRAMAFIC XENOLITHS AND MEGACRYSIS IN TERTIARY BASALTS
}

$$
\text { Fodor, }{ }^{(1)} \text { R.V.; Gandhok; }{ }^{(1)} \text { G.R.; and Sial, }{ }^{(2)} \text { A.N. }
$$

(1)North Carolina State University, Raleigh, NC 27695, USA.; (2)Universidade Federal de Pernambuco, Recife, PE, Brazil

Tertiary (13-31 Ma) alkalic basaltic centers in northeastern Brazil contain lherzolite and harzburgite xenoliths and pyroxene megacrysts. Plate reconstruction places these basaltic centers near the Fernando de Noronha hotspot during their times of eruption. We determined the compositions of basalts at four of these centers (three in Rio Grande do Norte state and one in Pernambuco state), and trace element and mineral compositions of their ultramafic xenoliths and xenocrysts. The geographic distances represented by these four sites spans about $200 \mathrm{~km} \mathrm{n}$-s.

Results: Basalts are olivine-phyric and have high Mg\#s (68-73), K20 1.2-1.3 wt.\%, Ni 300-350 ppm, Sr 600-900 ppm, Zr 155-225 ppm, and $\mathrm{La} / \mathrm{Yb}$ 19-27. Xenoliths have Fo 89-91, opx and cpx Mg\#s of 8892, and spinel Cr\#s of 9-39. Notable is that pyroxene compositions define two groups of xenoliths: (i) coexisting low-Wo opx and high-Wo cpx $($ Wo $<1$ and Wo $>45$ ), and (ii) coexisting high-Wo opx and low-Wo cpx (Wo>2 and Wo<44). These compositions respectively describe two regimes of pyroxene equilibration temperatures, $750-950^{\circ} \mathrm{C}$ and 1050-1200 ${ }^{\circ} \mathrm{C}$ (based on Wells, 1977). The three Rio Grande do Norte centers each have xenoliths of both types; only the low-T type was observed at the Pernambuco xenolith site. Pyroxene compositional characteristics associated with these two groups include: lower $\mathrm{Cr}$ and higher $\mathrm{Na}$ in cpx and lower $\mathrm{Cr}$ and $\mathrm{Na}$ in opx of the low-Wo opx (i.e. low-T) group when compared to cpx and opx in the high-Wo opx (i.e. high-T) group. Spinel Cr\#s are lowest (9-18) in the low-T group and higher (26-39) in the high-T group. Also, $\mathrm{CaO}$ is lower in o1 of the low-T group, $\leq 0.02 \mathrm{wt} . \%$, compared to $\mathrm{CaO}$ in olivine of the high-T group, $\geq 0.09$ wt. $\%$. Finally, the low-T group has flat patterns for middle-to-heavy REE at 2-3 x chondrites, and LREE enrichment where $\mathrm{La}(\mathrm{n})$ is 5-15 (analyses of cpx also show LREE enrichment); patterns for the high-T group are either flat at M-H REE ( chondritic values) or U-shaped (MREE(n) 0.01), and with $\mathrm{La}(\mathrm{n}) 2-3$.

Orthopyroxene and clinopyroxene megacrysts have compositions consistent with the type II (high-A1, low-Cr augite) group of xenoliths in basalts. An opx-cpx pair provides $1260^{\circ} \mathrm{C}$ equilibrium temperature. 
Conclusions: High $\mathrm{MgO}$ and $\mathrm{Ni}$ in the basalt hosts are consistent with near-primary melts from mantle peridotite; however, accurate assessment of $\mathrm{Mg0}$ is complicated by the presence of olivine disaggregated from the xenoliths. Xenolith geothermometry and corresponding mineral compositions (e.g. high-T group has higher spinel Cr\#s, lower $\mathrm{Na}$ and higher $\mathrm{Cr}$ in $\mathrm{cpx}$ ) suggest that the northeastern Brazil basalt centers contain samples of mantle that had a vertical gradient in terms of temperature and degree of melting, where the high-T xenoliths have mineral and trace-element compositions that reflect mantle more refractory than that represented by the low-T xenoliths. The megacrysts indentify metasomatic veining in this environment. Subsequent to (or associated with) the melting events that created distinct compositional (and equilibrium temperature) mantle zones, small-percent LREE-rich fluids infiltrated the environment. LREE abundances suggest that all mantle environments represented by the xenolith samples underwent enrichment; higher total REE concentrations now reside in members of the low-T group possibly because this material was not as depleted prior to fluid infiltration. These mantle samples from northeastern Brazil, therefore, offer an unusual perspective of vertical compositional "stratigraphy" related to temperature, melting, and the results of metasomatic events within subcontinental mantle. 